\title{
1997 ESACP consensus report on diagnostic DNA image cytometry
}

\section{Part I: Basic considerations and recommendations for preparation, measurement and interpretation}

\author{
G. Haroske ${ }^{\text {a }}$, F. Giroud ${ }^{\text {b }}$, A. Reith ${ }^{\mathrm{c}}$ and A. Böcking ${ }^{\mathrm{d}}$ \\ a University of Technology, Dresden, Germany \\ b University “Joseph Fourier”, Grenoble, France \\ ${ }^{\mathrm{c}}$ The Norwegian Radium Hospital, Oslo, Norway \\ d University "Heinrich Heine”, Düsseldorf, Germany
}

Received 2 December 1998

Revised 2 December 1998

Accepted 2 December 1998

\begin{abstract}
A task force of invited experts in the field of diagnostic DNA image cytometry, especially consisting of participants from the PRESS (Prototype Reference Standard Slides) and EUROPATH (European Pathology Assisted by Telematics for Healthcare) projects, but open to any other scientist or physician revealing experience in that new diagnostic procedure (names are given in the Annex A) agreed upon the following updated consensus report during the 5th International Congress of the ESACP 1997 in Oslo. This report is based on the preceeding one [9] and on results of the above mentioned European research projects. It deals with the following items:
\end{abstract}

- Biological background and aims of DNA image cytometry,

- Principles of the method,

- Basic performance standards,

- Diagnostic interpretation of DNA measurements,

- Recommendations for practical use.

Readers are invited to contribute remarks and comments on DNA ploidy through:

http://www.esacp.org/esacimag.html

\section{Biological background and aims of DNA image cytometry}

Quantitation of nuclear DNA content by cytometry has come into practice for assistance in the diagnosis and grading of malignant tumours. The DNA content cannot be measured directly by cytometry. After 
quantitative DNA-staining, the nuclear IOD (Integrated Optical Density) is the cytometric equivalent of its DNA content. The quantitation of nuclear DNA requires a rescaling of the IOD values by comparison with those from cells with known DNA content. Therefore the DNA content is expressed in a "c" scale in which 1c is half the mean nuclear DNA content of cells from a normal (non-pathological) diploid population in G0/G1 cell cycle phase.

For practical reasons as a term being accepted and used throughout the literature "DNA ploidy" will be further used. However, we want to point out that in practice the cytometric evaluation of nuclear DNA content is often improperly called "DNA ploidy" which is assumed to be the quantitative cytometric equivalent of "chromosomal ploidy". Both terms are not identical. Whereas "chromosomal ploidy" is theoretically detectable by cytogenetic methods in each single cell, its DNA content cannot be equated with a certain chromosomal outfit $[56,57,60]$. The term "DNA ploidy" should therefore preserved for the description of DNA stemlines, but not for single cells.

Indeed, the quantity of nuclear DNA may be changed by the following mechanisms: replication, polyploidization, gain or deletion. Each affects the size or the number of chromatids. Furthermore viral infections may change the nuclear DNA content detectable by flow and image cytometry. Among others, the unspecific effects of cytostatic or radiation therapy, vitamin B12 deficiency, apoptosis, autolysis and necrosis on nuclear DNA content play also a role $[5,13,49,58,61,64]$.

All these effects have to be taken into consideration when a diagnostic interpretation of DNA histograms is performed.

At present the basic aim of diagnostic DNA cytometry is to identify DNA stemlines outside the euploid regions as abnormal (or aneuploid) at a defined statistic level of significance. Furthermore DNA image cytometry should give information about

- Number of abnormal (sive aneuploid) DNA stemlines,

- Polyploidization of euploid or aneuploid DNA stemlines,

- Cell cycle fractions,

- Occurrence of rare cells with an abnormally high DNA content.

During the past few years a huge body of methodological experience has been gathered allowing ICM-DNA users to perform their DNA measurements at a high level of quality. Recommendations for the entire process of preparation and measurement are given in Annex B.

\section{Principles of the method}

Because DNA image cytometry results in nuclear IOD values, equivalent but not identical with nuclear DNA content, the quantitation of nuclear DNA requires a rescaling of IOD values by comparison with those from cells with known DNA content, so-called reference cells. By means of reference cells the arbitrary unit scale (a.u.) will be transformed in a reference unit scale $(2 c, 4 c, 8 c$, for example) $[16,56]$. In general, there are two types of reference cell systems: external and internal ones, respectively. Whereas the external reference cells are very easily to identify by the investigator, but often not to prepare in parallel with the clinical sample, the internal reference cells have the advantage of sharing all preparatory steps with the anlysis cells in the clinical specimens.

The nuclear IOD values of reference cells own the same methodological limitations in terms of precision of the measurements as the appropriate IOD values of the analysis cells. 
The mean ratio between the modal IOD values of the non-pathologic cells of the tissue under study and the reference cells used is called corrective factor. This corrective factor must be applied to DNA measurements from the clinical sample before any DNA histogram interpretation [56]. Due to the methodological variability, mentioned above, the corrective factor is not constant. The accuracy of each diagnostic DNA evaluation depends decisively on the standard deviation (SD) of the corrective factor used during the rescaling procedure [30].

Because most of the interpretations of DNA measurements are population-based, the results are usually displayed as DNA histograms. The bin size of such histograms should be adapted to the precision of the actual measurements, i.e., the lower the variability in the reference cell peak, the smaller the bin size of histogram classes could be.

The grammalogues "ICM-DNA" (image cytometric DNA) and "FCM-DNA" (flow cytometric DNA) are good descriptors used to designate the type of nuclear DNA measurement.

\section{Basic performance standards}

The usual precision of recent DNA image cytometric measurements should at least allow DNA stemlines to be identified as abnormal (or aneuploid), if they deviate more than $10 \%$ from the diploid (2c) or tetraploid region (4c), i.e., if they are outside $2 \pm 0.2 \mathrm{c}$ or $4 \pm 0.4 \mathrm{c}$.

To achieve this goal with an error probability $p<0.05$ the test statistics [30] require a measurement performance described by:

- the CV of the ratios between modal IOD-values of reference cells and non-pathologic G0/1 cells in a series of measurements is $<5 \%$ (comp. Fig. 1: SD of the peak position);

- the relative standard error ( $\mathrm{rSEM}=\mathrm{CV} / \sqrt{n}$ ) of reference cells in each sample is $<1.5 \%$.

Furthermore, a DNA-stemline should be identified as polyploid within the duplication position of a G0/1-phase-fraction $\pm 0.2 \mathrm{c}$ (at $4 \mathrm{c}$ ), and $\pm 0.4 \mathrm{c}$ (at $8 \mathrm{c}$ ), respectively, with an error probability $p<0.05$ if

- the CV of the ratios between modal IOD-values of non-pathologic G0/1- and G2/M-phase-fractions in a series of measurements is $<2.5 \%$.

Every scientist and physician who applies DNA image cytometry is free to choose his appropriate methodological specification, if he only meets the performance standards above.

The different aspects of the measuring process and of the interpretation should be regularly subjected to quality control measures in order to warrant a steadily high level of quality of the diagnostic procedure. Appropriate protocols for such a quality assurance guide are described in Part II of this paper.

\section{Diagnostic interpretation of DNA measurements}

\subsection{Definition of basic terms of ICM-DNA assessment (for illustration see Fig. 1)}

- DNA histogram: frequency distribution of IOD values obtained by quantitative DNA stains and rescaled by reference cells in "c" units. The class width should be twice the standard deviation of the IOD of the G0/1-phase-fraction of reference cells.

- Histogram peak: a significant local maximum in the DNA histogram. 


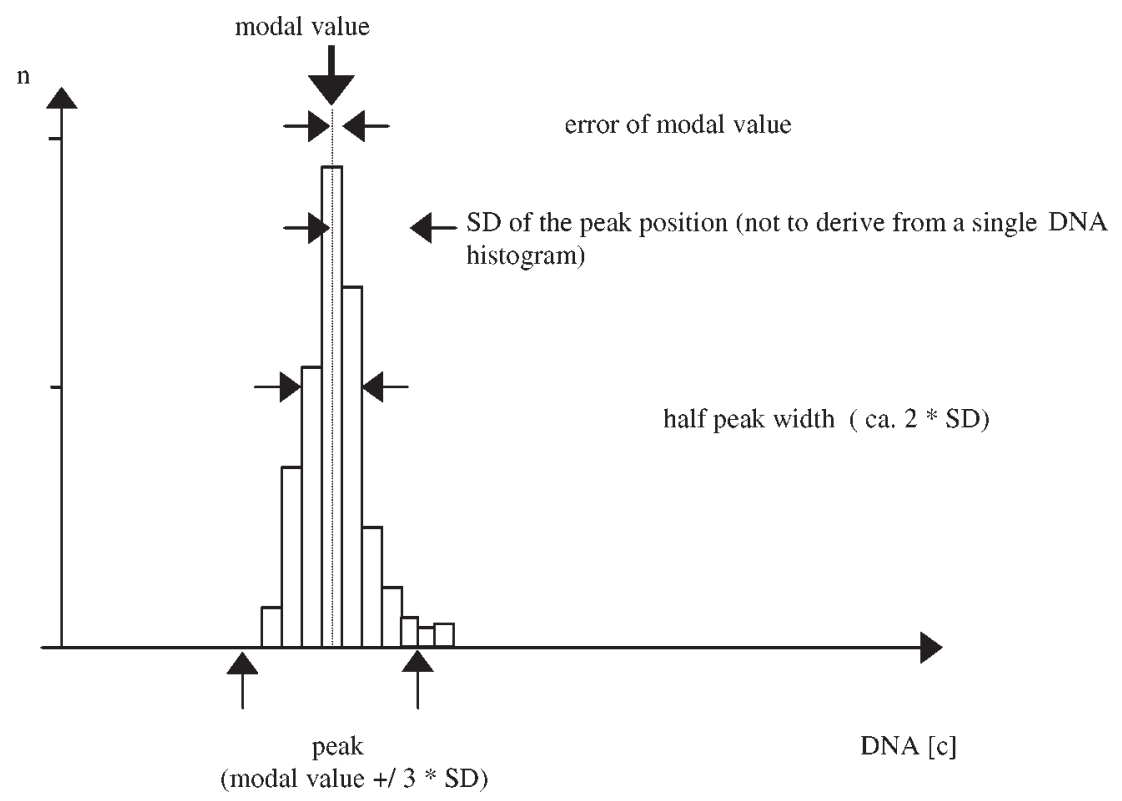

Fig. 1. Descriptors of a DNA histogram peak.

- Modal value of a histogram peak: the most frequent value, i.e., the mean value of the histogram class containing the highest number of nuclei.

- Corrective factor: mean ratio between the modal IOD values of the G0/1-phase-fractions of nonpathologic cells and of reference cells in a series of measurements under the same methodological conditions.

- DNA-stemline: G0/G1-phase-fraction of a proliferating cell population.

- DNA-G0/1-phase-fraction: all nuclei belonging to a peak which does not represent a duplication of a lower peak.

- DNA-G2/M-phase-fraction: all nuclei belonging to a peak in the duplication region of a G0/G1phase-fraction.

- DNA-S-phase-fraction: all nuclei with IOD-values in between those of the corresponding G0/1- and its $\mathrm{G} 2 / \mathrm{M}$-phase-fraction counterpart, and not belonging to other stemlines.

- DNA-euploidy: that type of DNA distributions which cannot be differentiated from those of normal (resting, proliferating, or polyploidizing) cell populations.

- DNA-aneuploidy: those types of DNA distributions which are statistically different from those of normal (resting, proliferating, or polyploidizing) cell populations.

- DNA-polyploidy: the occurrence of peaks in the duplication $(\times 2, \times 4, \times 8, \ldots)$ regions of euploid or aneuploid DNA-stemlines.

\subsection{Algorithms}

Depending on the material under investigation, the clinical or diagnostic question and the sampling strategy DNA measurements can be interpreted for three purposes [12], namely by assisting in: (1) the diagnosis of neoplasia, (2) the prognostication of neoplasia, and (3) the monitoring of the therapy.

The interpretation of the measurements should not be based on subjective interpretations but be defined by algorithms. The algorithms for the recognition of histogram peaks and their quantitation are 
recommended to be applied to the rescaled DNA measurement values directly, not to the binarized DNA histogram.

The following algorithms have been tested to be useful:

(1) Histogram peak: a local maximum statistically different $(p<0.05)$ from randomly distibuted events in the frequency distribution (for the type of the statistical test, e.g., see [30]).

(2) DNA-index (DI) of a peak: modal value of the peak divided by the modal value of the diploid reference cell peak [33].

(3) DNA stemline ploidy: modal value of a stemline in the "c" units, i.e., DI $* 2$ c [13,40,51].

(4) DNA-stemline abnormality (aneuploidy): modal value of the peak is outside the $95 \%$ confidence region of the modal value of G0/G1 phases of non-pathologic (DNA-euploid) cell populations measured under the same methodological conditions [30]. That means that an aneuploid peak is below or above 2c, $4 \mathrm{c}$, or $8 \mathrm{c}$, multiplied by the actual corrective factor, $\pm 2 * \mathrm{SD}$ of that corrective factor.

(5) Polyploidization: modal value of a measured stemline is not outside the $95 \%$ confidence region for the duplicate position, measured in a larger series of non-pathologic, polyploid cell populations under the same methodological conditions [30].

(6) For prognostic purposes a classification of the entire DNA histogram is proposed, according to the position of the DNA stemlines. The terms to classify the histogram for prognostication should be different from those ones used to identify DNA aneuploidy for diagnostic purposes. Principally the prognostic interpretation must be tumour type specific. Based on previous studies and taken tumour cytogenetics into account $[1,10,11,23,59]$ the following DNA histogram types are helpful in describing the prognosis of solid tumours:

- peridiploid: a single DNA-stemline has a modal DNA value between 1.8 and 2.2c;

- peritetraploid: a single DNA-stemline or a stemline additional to a peridiploid one has a modal DNA value between 3.6 and $4.4 \mathrm{c}$;

- x-ploid: a single DNA-stemline or a DNA-stemline additional to a peridiploid or peritetraploid one has a modal DNA value outside the thresholds mentioned above. " $x$ " should be substituted by the DNA ploidy value of this stemline (e.g., peritriploid, hyperdiploid, etc.);

- multiploid: more than one abnormal DNA-stemline occurs (often called "Manhattan skyline").

For each histogram type the exact position of the stemline should be given. However, one has to take into consideration that the prognostic relevance of these classes may be different among the various tumour types.

(7) Abnormal cells, often called 5c exceeding events or 9c exceeding events, are those cells having nuclear DNA content higher than the duplication or quadruplication region of a normal G0/G1 phase population, i.e., not belonging to $\mathrm{G} 2 / \mathrm{M}$ phase fractions. Cave: 5 or $9 \mathrm{c}$ are often not approriate thresholds for defining abnormality due to the improper precision of the measurements. The choice of the duplication or quadruplication region depends on the occurence of euploid polyploidization in the tissue under investigation $[6-8,14,47]$.

Those abnormal cells can be given as absolute numbers or as rates (related to the number of all cells measured).

(8) Cell cycle fractions should only be quantitated, if a single DNA stemline has been recognized. The G0/1- as well as the G2/M-phase-fractions comprise all nuclei with DNA values in a region of the modal value \pm 3 times the SD of the corresponding peaks (see Fig. 1).

In calculation of cell cycle fractions, especially in those with low cell numbers, the statistical limitations given by those actual cell numbers must be regarded [30]. So far, there are not enough sufficient 
data as to evaluate the relevance of cell cycle phase measurements by DNA-ICM. The application of cell cycle fraction quantitation in diagnostics is therefore out of the scope of this consensus.

(9) Further complex algorithms for interpretation:

- 2c Deviation Index (2cDI) [7]:

$$
2 \mathrm{cDI}=\sum_{i=1}^{n} \frac{\left(\mathrm{c}_{i}-2 \mathrm{c}\right)^{2}}{n} .
$$

$\mathrm{c}_{i}$ is the DNA content of a single nucleus, rescaled by the mean corrective factor of the tissue type under investigation.

- ploidy balance (PB) [46]:

$$
\mathrm{PB}=\frac{\left(n_{\mathrm{eu}}-n_{\mathrm{an}}\right)}{N} \cdot 100 .
$$

$n_{\mathrm{eu}}$ is the number of all cells in euploid regions of the DNA histogram rescaled by the mean corrective factor of the tissue type under investigation $(1.8-2.2 \mathrm{c} ; 3.6-4.4 \mathrm{c} ; 7.2-8.8 \mathrm{c})$;

$n_{\text {an }}$ is the number of all cells outside the euploid regions of rescaled DNA histogram;

$N$ is the total number of cells.

In conclusion, for the diagnosis of malignancy the DNA-stemline abnormality and/or the occurence of abnormal cells should be regarded. For the prognostication of a known malignant lesion the prognostic histogram types and/or the complex algorithms are recommended.

Before a more detailed and tumour type specific diagnostic interpretation can be proposed, the algorithms above have to be tested in large scale clinical materials in a standardized manner, i.e., regarding the recommendations and basic considerations of this consensus. An immanent part of this methodological standardization must be the approriate quality assurance, given in Part II of this paper.

\section{Annex A}

Participants in the consensus session during the 5th International Congress of the ESACP 1997 in Oslo:

V. Abeler, Oslo, Norway; L. Angvaldson, Lund, Sweden; M. Aubele, Munich, Germany; J.A.M. Belien, Amsterdam, the Netherlands; A. Berner, Oslo, Norway; St. Biesterfeld, Aachen, Germany; D. Bloyet, Caen, France; A.-K. Borander, Oslo, Norway; G. Brugal, Grenoble, France; C. Busch, Uppsala, Sweden; H.-K. Choi, Kim-Hae, Korea; H.E. Danielsen, Oslo, Norway; F. Dodman, Oslo, Norway; H.P. Dong, Oslo, Norway; H. Dower, Oslo, Norway; J. Dufer, Reims, France; P.-O. El Guedos, Caen, France; V. Enchev, Sofia, Bulgaria; J. Erenpreisa, Riga, Latvia; L. Franzen, Linkøping, Sweden; K. Friedrich, Dresden, Germany; W. Harber, Oslo, Norway; G. Haroske, Dresden, Germany; P. Herlin, Caen, France; M. Hubler, Basel, Switzerland; J. Kalabis, Brno, Czechoslovakia; K. Kayser, Heidelberg, Germany; P. Kiehl, Hannover, Germany; G. Klorin, Haifa, Israel; D. Kunze, Dresden, Germany; D. Lage, Oslo, Norway; G. Luciano, Padova, Italy; T. Linden, Lund, Sweden; H. Lyon, Copenhagen, Denmark; C. MacAulay, Vancouver, Canada; K. Makoto, Hamamatsu, Japan; E. Malberger, Haifa, Israel; E. Masson, Caen, France; W. Meyer, Dresden, Germany; B. Moser, Munich, Germany; A. Orbo, 
Troms $\varnothing$, Norway; P. Prytz, Troms $\varnothing$, Norway; K.-A. Reiffen, Darmstadt, Germany; A. Reith, Oslo, Norway; G. Remkers, the Netherlands; W. Reuter, Heerbrugg, Switzerland; G. Richartz, Duisburg, Germany; H. Schulerud, Oslo, Norway; E. Schulte, Mainz, Germany; P. Spieler, St. Gallen, Switzerland; M. Sueo, Hamamatsu, Japan; H. Swethurst, Trondheim, Norway; F. Theissig, Dresden, Germany; J.-M. Theler, Switzerland; B. Tribukait, Stockholm, Sweden; J. Tucker, Edinburgh, UK; N. Urban, Oslo, Norway; M. van der Linden, Cambridge, UK; P. van Diest, Amsterdam, the Netherlands; A. Wahlefeld, Penzberg, Germany.

\section{Annex B. Methodological recommendations}

\section{B.1. Preparation of cytologic specimens}

\section{B.1.1. Samples}

Cell culture monolayers, imprints (touch preparations), smears from fine needle aspiration biopsies (FNAB), smears from exfoliated cells, cytocentrifuged preparations from body fluids, cell separation specimens (after mechanic and/or enzymatic dispersion) from FNABs, core- or other biopsies or from formaldehyde-fixed, paraffin embedded tissues may be used [18,19,24,31,32,34,35,62]. The enzymatic procedures for isolating cells of different tissue types have to be carefully worked out for every type to achieve sufficient yields of structurally intact cells. As a general rule one can consider a $1 \%$ pepsin digestion for $30 \mathrm{~min}$ at $37^{\circ} \mathrm{C}$ to be adequate.

At present measurements of the DNA content in tissue sections do not meet the performance standards mentioned above.

\section{B.1.2. Fixation}

Fixation with formaldehyde is necessary before staining by the Feulgen reaction with pararosaniline or thionine $[25,26]$. One possible procedure is to air dry the samples at room temperature for at least $1 \mathrm{~h}$. Then fix in $4 \%$ paraformaldehyde during $30 \mathrm{~min}$ and rinse in distilled water [e.g., 4\% paraformaldehyde

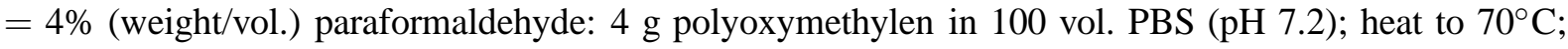
cool to room temperature; filter]. All other types of fixatives, which should be applied after air drying and which should contain formaldehyde anyway, should be tested by the appropriate quality control procedure (see Part II - Quality control for DNA staining). In this respect the Böhm-Sprenger fixative (modified solution: methanol $80 \%$, formalin 15\%, acetic acid 5\%) has been tested and found to be suitable [28].

Prestained smears may also be used. Postfixation after uncovering is necessary according to the above mentioned procedure $[2,3,18,25,39,45]$. The same is especially important for monolayer preparations prepared from paraffin sections.

Whatever the fixative used, the samples should be strongly washed: rinsing after fixation in formaldehyde containing solutions is crucial to remove residual formaldehyde to avoid unspecific staining.

\section{B.1.3. Staining}

Feulgen reaction is strictly recommended in absorption cytometry. This reaction is a cytochemical procedure necessarily done in two steps: (1) hydrolysis to obtain aldehyde groups by depurination and (2) staining the aldehyde groups using the Schiffs reagent leading to a color complex.

Avoid treating big batches of slides in the same bath: working out a maximum of 20 slides for $200 \mathrm{ml}$ of solution, including optionally one or more reference slides and a negative control is recommended. Check that covered surfaces of slides are correctly exposed to reagents. Use gentle agitation. 
Table 1

Properties of dyes used for DNA image cytometry

\begin{tabular}{lllll}
\hline Dye & $\begin{array}{l}\text { Absorption } \\
\text { maximum }\end{array}$ & $\begin{array}{l}\text { Color index } \\
\text { name }\end{array}$ & $\begin{array}{l}\text { Color index } \\
\mathrm{nr}\end{array}$ & $\begin{array}{l}\text { Chemical abstract } \\
\mathrm{nr}\end{array}$ \\
\hline Pararosaniline & $560 \mathrm{~nm}$ & Basic red 9 & 42500 & $569-61-9$ \\
Thionine & $590 \mathrm{~nm}$ & No CI name & 52000 & $78338-22-4$ \\
\hline
\end{tabular}

Table 2

Protocol for Feulgen staining, following the final rinsing step after fixation (tested in the PRESS project [26])

\begin{tabular}{llcl}
\hline Procedure & Substance & Condition & Time and temperature \\
\hline Hydrolysis & $\mathrm{HCl}$ & $5 \mathrm{~N}$ & 60 min at $25^{\circ} \mathrm{C}$ \\
Rinsing & $\mathrm{H}_{2} \mathrm{O}$ (distill.) & 4 bathes & 1 min each bath at room temperature \\
Staining & Schiffs reagent & & 60 min at $25^{\circ} \mathrm{C}$ \\
& Sulfite solution* & 4 bathes & 1 min each bath at room temperature \\
Rinsing & Tap water & & 10 min at room temperature \\
Dehydration & $\mathrm{H}_{2} \mathrm{O}$ (distill.) & $3 \mathrm{~min}$ & \\
& Alcohol 70\% & $5 \mathrm{~min}$ & \\
& Alcohol 95\% & $3 \mathrm{~min}$ & \\
& Alcohol 95\% & $5 \mathrm{~min}$ & \\
& Alcohol 100\% & $3 \mathrm{~min}$ & \\
& Alcohol 100\% & $10 \mathrm{~min}$ & \\
Mounting & Toluene & $5 \mathrm{~min}$ & \\
& Toluene & 5 min & \\
& Mounting medium & Coverslide & \\
Keep the slides at & $4^{\circ} \mathrm{C}$ out of light before analysis
\end{tabular}

* Sulfur bathes are prepared extemporaneously: Na or K metabisulfite $5 \mathrm{~g}, \mathrm{HCl} 1 \mathrm{~N} 50 \mathrm{ml}$, adjust to $1000 \mathrm{ml}$ with $\mathrm{H}_{2} \mathrm{O}$ (distill.).

Hydrolysis conditions for Feulgen have to take tissue type, fixation (type of fixative, time and concentration) and mode of sample preparation into account. Optimal staining conditions have to be worked out, based on hydrolysis curves (time vs. IOD = integrated optical density). For each new type of material hydrolysis curves should be obtained. Hydrolysis has to be performed under controlled temperature and time conditions. Stop hydrolysis by rinsing in distilled water.

Evaluation of the performance of staining conditions should be done running the appropriate quality control procedure (see Part II - Quality control for DNA staining).

The following conditions are suitable for many routine applications and have been largely tested in the case of smears or imprints initially air dryed: $5 \mathrm{M} \mathrm{HCl}, 25^{\circ} \mathrm{C}$ and $1 \mathrm{~h}$ (if not otherwise demanded by the hydrolysis curves).

Staining: use Schiffs reagent [pararosaniline (red) or thionine (blue)] during $1 \mathrm{~h}$ under temperature controlled conditions at $25^{\circ} \mathrm{C}$. Use sulfite rinse to remove surplus dye from the cell nuclei and cytoplasm.

Commercial Schiffs reagent is often prepared from basic fuchsine which is a dye mixture of relatives of pararosaniline. The limit of shelf life of pararosaniline and thionine solutions is about 1 year and 2 weeks, respectively $[15,22,28,38,41-44,52-55,63]$. 
Negative control: specificity control of the Feulgen reaction may be performed by staining an unhydrolysed specimen which must remain unstained.

The use of fluorochromes for DNA staining and subsequent measurements of fluorescence intensities is out of the scope of this consensus.

Use of appropriate commercial solutions and so-called Feulgen kits is also possible.

\section{B.2. Instrumentation requirements for densitometric measurements}

Setting up the system: (1) Use different interference filters for blue (thionine, e.g., $590 \pm 10 \mathrm{~nm}$ ) or red (pararosaniline, e.g., $560 \pm 10 \mathrm{~nm}$ ) stain. (2) Perform Köhler illumination. (3) Perform analogue and digital adjustments (the so-called "offset" and "gain" setting) for correct light intensity. (4) Adjust "offset" and "gain" before each measurement.

System quality assurance: (1) Check stability over time. (2) Check densitometric linearity. (3) Check for shading phenomena. (4) Check for glare phenomena $[4,16,20,21,28,29,36,37,41,44,48,50]$.

Corresponding quality assurance protocols are given in Part II (Quality control of ICM instrumentation).

\section{B.3. Densitometric measurements}

(1) Nuclei to be measured must be in focus. (2) No change of instrumentation adjustment during measurements: Köhler-illumination, light intensity, field diaphragm, analogue and digital adjustment. (3) Correct for shading by software procedures. Acquisition at the position of the optical axis is recommended. (4) Correct for local background per nucleus by software procedures. (5) Correct for glare (straylight) by software procedures [29]. (6) Use visual control during and/or after measurements for artefact rejection, correct focus and appropriate segmentation.

Evaluation of the performance of densitometric measurements procedure should be done running the appropriate quality control procedure (see Part II - Quality control for segmentation).

\section{B.4. Reference cells}

(1) In clinical samples internal reference cells should be preferred. Lymphocytes, granulocytes, normal epithelial cells or stroma cells can be analysed as internal standards. Diploid rat liver hepatocytes may be used as external standard. (2) External reference cells should be prepared and fixed identically as cells under analysis. Deposition of the external reference cells on the same slide as the the clinical sample is recommended. External reference cells should be stained in the same staining bathes as the clinical sample. (3) All reference cells should be analysed during the same run as the clinical sample and under the same conditions. The coefficient of variation (CV) of the IOD of the G0/1-phase-fraction of reference cells should not exceed $5 \%(\mathrm{CV}=(\mathrm{SD} /$ mean $) \times 100)($ see above and $[17,45,61])$.

\section{B.5. Scaling procedure}

(1) Use reference cells to transform the arbitrary unit scale (a.u.) in a reference unit scale (2c, $4 c, 8 c$, for example). (2) Make estimation of the ratio between the mean IOD values of the reference cells used and normal cells of the tissue under study, this will define a corrective factor. (3) Apply the corrective factor to DNA measurements from the clinical sample before DNA histogram interpretation. The accuracy of each diagnostic DNA evaluation depends decisively on the standard deviation (SD) of this corrective factor used during the scaling procedure. (See Part II - QC of the corrective factor.) 


\section{B.6. Sampling}

(1) Use a systematic random sampling strategy.

Diagnostically relevant cells should be measured only, i.e., cells of a certain cytological entity, e.g., all tumour cells or all dysplastic cells, which can be identified by their morphology.

Given a stochastic distribution of the cellular material by the method of cell deposition (cytocentrifugation), a random sampling can be achieved by a systematic measurement of cells under the microscope. Therefore, the cell selection should, for example:

- start at a point inside a region where the cellular material is evenly distributed;

- proceed cell by cell in one field of view;

- be continued with the next field of view;

- include sampling of the internal reference cells in the same fields of view.

(2) A selective sampling for rare nuclei characterized by a high DNA content is allowed, if not the relative frequency of their occurence, but the occurence per se is of diagnostic relevance [12].

(3) A stochastic sampling should not be combined with a selective one, unless the rare nuclei are clearly flagged as such and are not included in a population-based interpretation.

(4) The number of cells measured defines the validity of the histogram properties, e.g., the number of peaks which can be identified. For recognizing a unimodal DNA histogram usually at least 50 cells have to be measured. The more peaks are expected, the higher is the necessary cell number to be measured.

\section{Acknowledgements}

The authors gratefully acknowledge the mathematical and statistical support as well as the technical assistance of Magali Puech, Ph.D., and W. Meyer, Ph.D., without their collaboration this consensus paper would not have been possible.

\section{References}

[1] X. Albe, P. Vassilakos, K. Helfer-Guarnori, J.C. Givel, N. deQuay, L. Suardet, J.F. Eliason and N. Odartchenko, Independent prognostic value of ploidy in colorectal cancer, Cancer 66 (1990), 1168-1175.

[2] M. Aubele, G. Burger and K. Rodenacker, Problems concerning quality of Feulgen DNA measurements: a study on five different fixation techniques, Analyt. Quant. Cytol. Histol. 16 (1994), 226-232.

[3] J.P.A. Baak, E. Noteboom and J.J.M. Koevoets, The influence of fixatives and other variations in tissue processing on nuclear morphometric features, Analyt. Quant. Cytol. Histol. 11 (1989), 219-224.

[4] K.S. Bedi and D.Y. Goldstein, Apparent anomalities in nuclear Feulgen-DNA contents. Role of systematic densitometric error, J. Cell Biol. 71 (1976), 6-88.

[5] S. Biesterfeld, K. Gerres, G. Fischer-Wein and A. Böcking, Polyploidy in non-neoplastic tissues, J. Clin. Pathol. 47 (1994), $38-42$.

[6] A. Böcking, DNA-Zytometrie und Automation in der klinischen Diagnostik, Beitr. Onkol. 38 (1990), 298-347.

[7] A. Böcking, C.P. Adler, H.H. Common, H.M. Hilgarth, B. Granzen and W. Auffermann, Algorithm for a DNA cytophotometric diagnosis and grading of malignancy, Analyt. Quant. Cytol. 6 (1984), 1-8.

[8] A. Böcking, S. Biesterfeld and S. Liu, DNA distribution in gastric cancer and dysplasia, in: Precancerous Conditions and Lesions of the Stomach, Y.-C. Zhang and K. Kawai, eds, Springer, Heidelberg, 1993, pp. 103-120.

[9] A. Böcking, F. Giroud and A. Reith, Consensus report of the ESACP task force on standardization of diagnostic DNA image cytometry, Anal. Cell. Pathol. 8 (1995), 67-74.

[10] A. Böcking, E. Striepecke, H. Auer and L. Füzesi, Static DNA cytometry. Biological background, technique and diagnostic interpretation, in: Compendium on the Computerized Cytology and Histology Laboratory, G.L. Wied, P.H. Bartels, D.L. Rosenthal and U. Schenck, eds, Tutorials of Cytology, Chicago, III., USA, 1994, pp. 107-128. 
[11] A. Böcking, E. Striepecke and L. Füzesi, Cytogenetic and cell-kinetic basis of diagnostic DNA cytometry, Verh. Dtsch. Ges. Path. (1994), 78.

[12] A. Böcking, DNA image cytometry. When and why?, in: Compendium on the Computerized Cytology and Histology Laboratory, G.L. Wied, P.H. Bartels, D.L. Rosenthal and U. Schenck, eds, Tutorials of Cytology, Chicago, IV., USA, 1995.

[13] N. Böhm and W. Sandritter, DNA in Human Tumours: A Cytophotometric Study, Springer-Verlag, Berlin, Heidelberg, New York, 1975.

[14] R. Chatelain, T. Schunck, E. Schindler, A. Schindler and A. Böcking, Diagnosis of prospective malignancy in koilocytic dysplasias of the cervix with DNA cytometry, J. Reprod. Med. (1989), 505-510.

[15] R. Chatelain, A. Willms, S. Biesterfeld, W. Auffermann and A. Böcking, Automated Feulgen staining with a temperaturecontrolled staining machine, Analyt. Quant. Cytol. Histol. 11 (1989), 211-217.

[16] P. Chieco, A. Jonker, C. Melchiorri, G. Vanni and C.J.F. van Noorden, A user's guide for avoiding errors in absorbance image cytometry: a review with original experimental observations, Histochem. J. 26 (1994), 1-19.

[17] H. Coen, M. Pauwels and F. Roels, The rat liver cell nuclear imprint as a standard for DNA measurements, Anal. Cell. Pathol. 4 (1992), 273-285.

[18] Y. de Launoit, R. Kiss and A. Ganguy, Influence of smear preparation and fixatives on the ploidy and the morphonuclear features of the MXT mammary tumour and normal tissues in the mouse, Cytometry 11 (1990), 691-699.

[19] R. Delgado, G. Mikuz and F. Hofstädter, DNA Feulgen cytophotometric analysis of single cells isolated from paraffin embedded tissue, Path. Res. Pract. 179 (1984), 92-94.

[20] W.A.L. Duijndam, A.W.M. Smeulders, P. van Duijn and A.C. Verweij, Optical errors in scanning stage absorbance cytophotometry. I. Procedures for correcting apparent integrated absorbance values for distributional glare and diffraction errors, J. Histochem. Cytochem. 28 (1980), 388-394.

[21] G. Exner and W. Schreiber, Mikrophotometrische Untersuchungen an Modellpräparaten, in: Optik und Spektroskopie aller Wellenlängen, Akademie Verlag, Berlin, 1962, pp. 236-245.

[22] R. Feulgen, and H. Rossenbeck, Mikroskopisch-chemischer Nachweis einer Nucleinsäure vom Typus der Thymonucleinsäure und die darauf beruhende elektive Färbung von Zellkernen in mikroskopischen Präparaten, Hoppe Seyler Z. Physiol. Chem. 135 (1924), 203-248.

[23] G. Forsslund and A. Zetterberg, Ploidy level determination in high-grade and low-grade malignant variants of prostatic carcinoma, Cancer Res. 50 (1990), 4281-4285.

[24] J.W. Geyer, F. Hancock, C. Carrico and J. Kirkpatrick, Preliminary evaluation of cyto-Rich: an improved automated cytology preparation, Diagn. Cytopathol. 9 (1993), 417-422.

[25] F. Giroud and M.P. Montmasson, Reevaluation of optimal Feulgen reaction for automated cytology: influences of fixations, Analyt. Quant. Cytol. Histol. 11 (1989), 87-95.

[26] F. Giroud, Prototype reference standard slides for quantitative cytometry of nuclear DNA content, Synthesis Report CEE/BCR_DGX11 MAT1_CT 930010, September 1996.

[27] G.J. Goldstein, Aspects of scanning microdensitometry. I. Stray light (glare), J. Microscop. 92 (1970), 1-16.

[28] W. Graumann, Zur Standardisierung des Schiff'schen Reagenz, Z. Wiss. Mikros. 61 (1953), 225-226.

[29] G. Haroske, W. Meyer, F. Theissig and K.D. Kunze, Increase of precision and accuracy of DNA cytometry by correcting diffraction and glare errors, Anal. Cell. Pathol. 9 (1995), 1-12.

[30] G. Haroske, V. Dimmer, W. Meyer and K.D. Kunze, DNA histogram interpretation based on statistical approaches, Anal. Cell. Pathol. 15 (1997), 157-173.

[31] D.W. Hedley, M. Friedlander and T.W. Taylor, Application of DNA flow cytometry to paraffin-embedded archival material for the study of aneuploidy and its clinical significance, Cytometry 6 (1985), 327-333.

[32] T. Heiden, H. Wang and B. Tribukait, An improved Hedley-method for preparation of paraffin-embedded tissues for flow cytometric analysis of ploidy and S-phase, Cytometry 12 (1991), 614-621.

[33] W. Hiddemann, J. Schumann, M. Andreef, B. Barlogie, C.J. Herman, R.C. Leif, B.H. Mayall, R.F. Murphy and A.A. Sandberg, Convention on nomenclature for DNA cytometry, Cancer Genetics and Cytogenetics 13 (1984), 181-183.

[34] A.J. Howat, G.R. Armstrong, W.A. Briggs, C.M. Nicholson and D.J. Stewart, Fine needle aspiration of palpable breast lumps: a 1-year audit using the cytospin method, Cytopathology 3 (1992), 17-22.

[35] M.L. Hutchinson, P. Agarwal, T. Denault, B. Berger and E.S. Cibas, A new look at cervical cytology. Thin Prep Multicenter Trial results, Acta Cytol. 36 (1992), 499-504.

[36] J.R. Jarvis, A microcomputer system for video image analysis and diagnostic microdensitometry, Analyt. Quant. Cytol. Histol. 8 (1986), 201-209.

[37] D. Kindermann and C.H. Hilgers, Glare correction in DNA image cytometry, Anal. Cell. Pathol. 6 (1994), 165-180.

[38] P. Kjellstrand, Temperature and acid concentration in the search for optimum Feulgen hydrolysis conditions, J. Histochem. Cytochem. 25 (1977), 129-134.

[39] V.M. Kotelnikov and L.L. Litinskaya, Comparative studies of Feulgen hydrolysis for DNA. 1. Influence of different fixatives and polyethylene glycols, Histochem. 71 (1981), 145-153. 
[40] M. Kropff, R. Chatelain, C.P. Muller, A. Wagner, T. Wenzler, H. Böhmer and A. Böcking, Monitoring DNA cytometric parameters during the course of chronic myelogenous leukemia, Analyt. Quant. Cytol. Histol. 13 (1991), 433-439.

[41] A. Krug, Histo- und Zytophotometrie, VEB Gustav Fischer-Verlag, Jenna, 1980.

[42] M.L.P. Larson and H. Sanaia, The Feulgen reaction: importance of the wash after hydrolysis, Acta Histochem. 67 (1980), $6-12$.

[43] H. Lyon, E. Schulte, B. de Leenherr et al., ECCLS-SRMTS-standards on dyes and stains. II. Thionine, Histochem. J. 24 (1992), 228-229.

[44] U.V. Mikel and R.L. Becker, A comparative study of quantitative stains for DNA in image cytometry, Analyt. Quant. Cytol. Histol. 13 (1991), 253-260.

[45] E. Munck-Wikland, C.A. Rubiro, G.U. Auer, R. Kuylenstierna and J. Lindham, Control cells for image cytometric DNA analysis of esophageal tissue and the influence of preoperative treatment, Analyt. Quant. Cytol. Histol. 12 (1990), 267-274.

[46] M. Opfermann, G. Brugal and P. Vassilakow, Cytometry of breast carcinoma: significance of ploidy balance and proliferation index, Cytometry 8 (1987), 217-224.

[47] J.J. Ploem-Zaaijer, M.E. Beyer-Boon, L. Leyte-Veldstra and J.S. Ploem, Cytofluorometric and cytophotometric DNA measurements of cervical smears stained using a new bicolor method, in: Automation of Cancer Cytology and Cell Image Analysis, N.J. Pressmann and G.L. Wied, eds, Tutorials of Cytology, Chicago, 1979, pp. 225-235.

[48] A. Reith and H. Danielsen, Assessment of DNA-ploidy in tumour material. Preparation and measurement by image cytometry, in: Compendium on the Computerized Cytology and Histology Laboratory, G.L. Wied, P.H. Bartels, D.L. Rosenthal and U. Schenck, eds, Tutorials of Cytology, Chicago, IL, USA, 1994, pp. 185-193.

[49] A.A. Sandberg, The Chromosomes in Human Cancer and Leukemia, 2nd edn, Elsevier, New York, Amsterdam, Oxford, 1990.

[50] L. Sanchez, M. Regh, S. Biesterfeld, R. Chatelain and A. Böcking, Performance of a TV image analysis system as a microdensitometer, Analyt. Quant. Cytol. Histol. 12 (1990), 279-284.

[51] W. Sandritter and M. Car, Cytophotometric measurements of the DNA content (Feulgen reaction) of malignant human tumours, Acta Cytol. 10 (1966), 26-30.

[52] E. Schulte, Air drying as a preparatory factor in cytology: investigation of its influence on dye uptake and dye binding, Diagn. Cytopathol. 2 (1986), 160-167.

[53] E. Schulte, Standardization on the Feulgen reaction for absorption. DNA image cytometry: a review, Analyt. Cell. Pathol. 3 (1991), 167-182.

[54] E. Schulte and D. Wittekind, Standardization of the Feulgen reaction: the influence of chromatin condensations on the kinetics of acid hydrolysis, Analyt. Cell. Pathol. 2 (1990), 149-157.

[55] E. Schulte and D. Wittekind, Standardization of the Papanicolaou stain. I. A comparison of five nuclear stains, Analyt. Quant. Cytol. Histol. 12 (1990), 149-156.

[56] E.K.W. Schulte, D. Seigneuring, F. Giroud and G. Brugal, DNA densitometry, in: Quantitative Clinical Pathology, P.W. Hamilton and D.C. Allen, eds, Blackwell Science, 1995, pp. 140-169.

[57] S.E. Shackney, D.R. Burholt, A.A. Pollice, C.A. Smith, R.P. Pugh and J. Hartsock, Discrepancies between flow cytometric and cytogenetic studies in the detection of aneuploidy in human solid tumours, Cytometry 11 (1990), 94-104.

[58] B. Stenkvist and G. Strande, Entropy as an algorithm for the statistical description of DNA cytometric data obtained by image analysis microscopy, Analyt. Cell. Pathol. 2 (1990), 159-165.

[59] B. Tribukait, L. Rönström and P.L. Esposti, Quantitative and qualitative aspects of flow DNA measurements related to the cytologic grade in prostatic carcinoma, Analyt. Quant. Cytol. 5 (1983), 107-111.

[60] B. Tribukait, I. Granberg-Öhmann and H. Wijkström, Flow cytometric DNA and cytogenetic studies in human tumours: a comparison and discussion of the differences in modal values obtained by the two methods, Cytometry 7 (1986), 194-199.

[61] B. Tribukait, G. Moberger and A. Zetterberg, Methodological aspects for rapid flow cytofluorometry for DNA analysis of human urinary bladder cells, in: Pulse Cytophotometry, Part I, C. Haenen, H. Hillen and S. Wessels, eds, European Press Medicon, Ghent, 1975, pp. 55-60.

[62] J.A. Tutuarima, E.A.H. Hische, R.M.R. Sylva-Steenland and H.J. van der Helm, A cytopreparatory method for cerebrospinal fluid in which the cell yield is high and the fluid is saved for chemical analysis, Acta Cytol. 32 (1988), 425.

[63] P. van Duijn, A histochemical specific thionine- $\mathrm{SO}_{2}$ reagent and its use in a bi-color method for deoxyribonucleic acid and preiodic acid-Schiff positive substances, J. Histochem. Cytochem. 4 (1956), 55-63.

[64] B. Winkler, C. Crum, T. Fujii, A. Ferenczy, M. Boon, L. Braun, W.D. Lancaster and R.M. Richart, Koilocytic lesions in the cervix, Cancer 53 (1984), 1081-1087. 


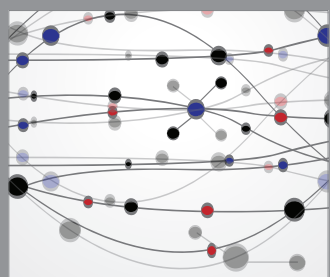

The Scientific World Journal
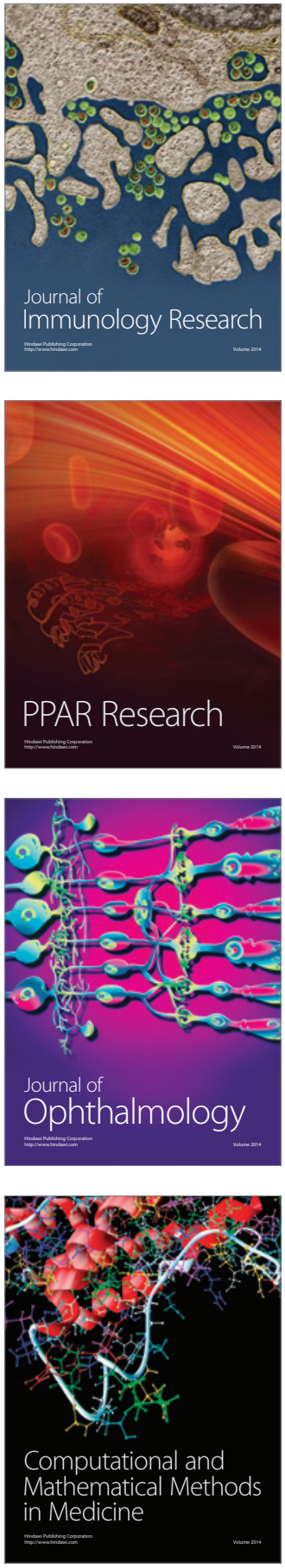

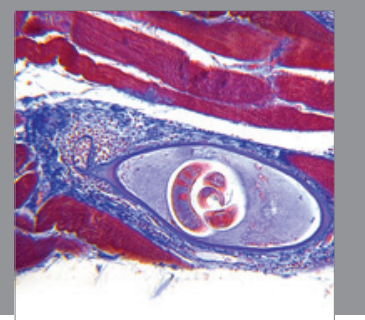

Gastroenterology

Research and Practice
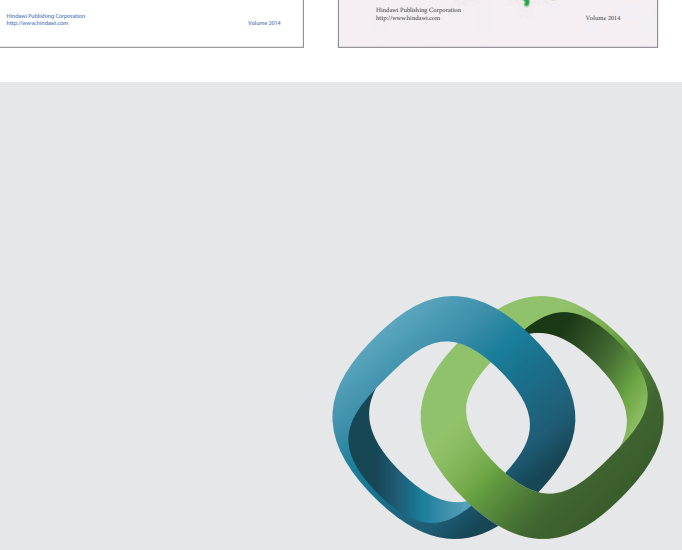

\section{Hindawi}

Submit your manuscripts at

http://www.hindawi.com
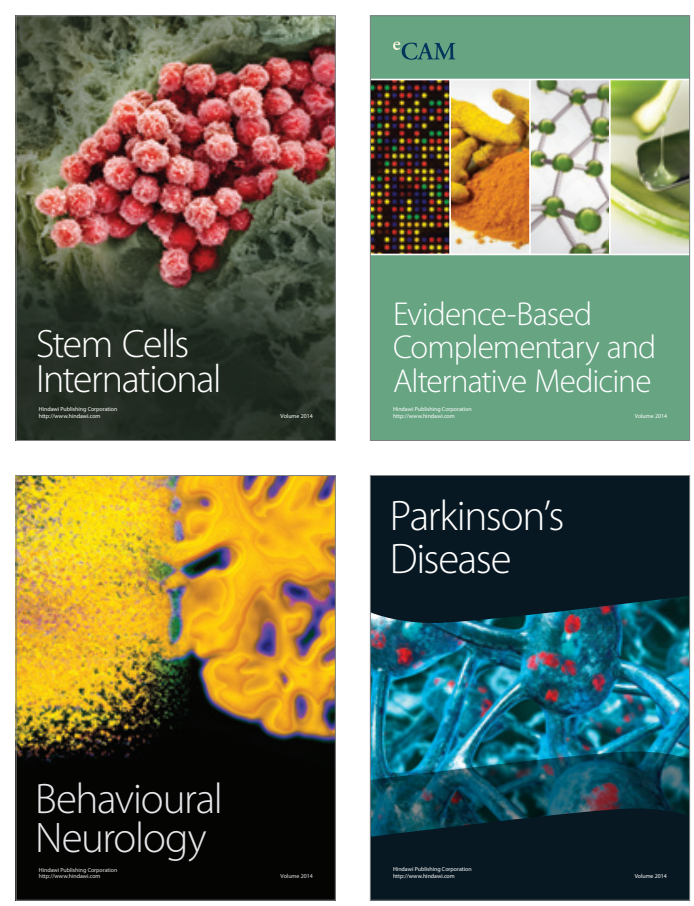

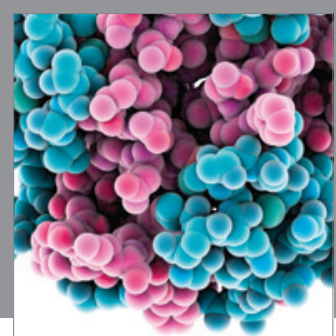

Journal of
Diabetes Research

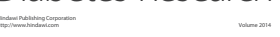

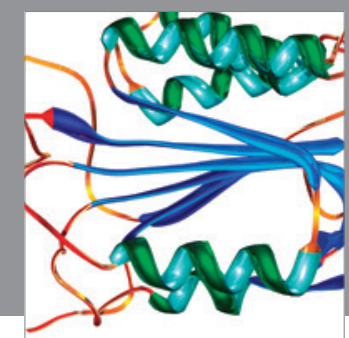

Disease Markers
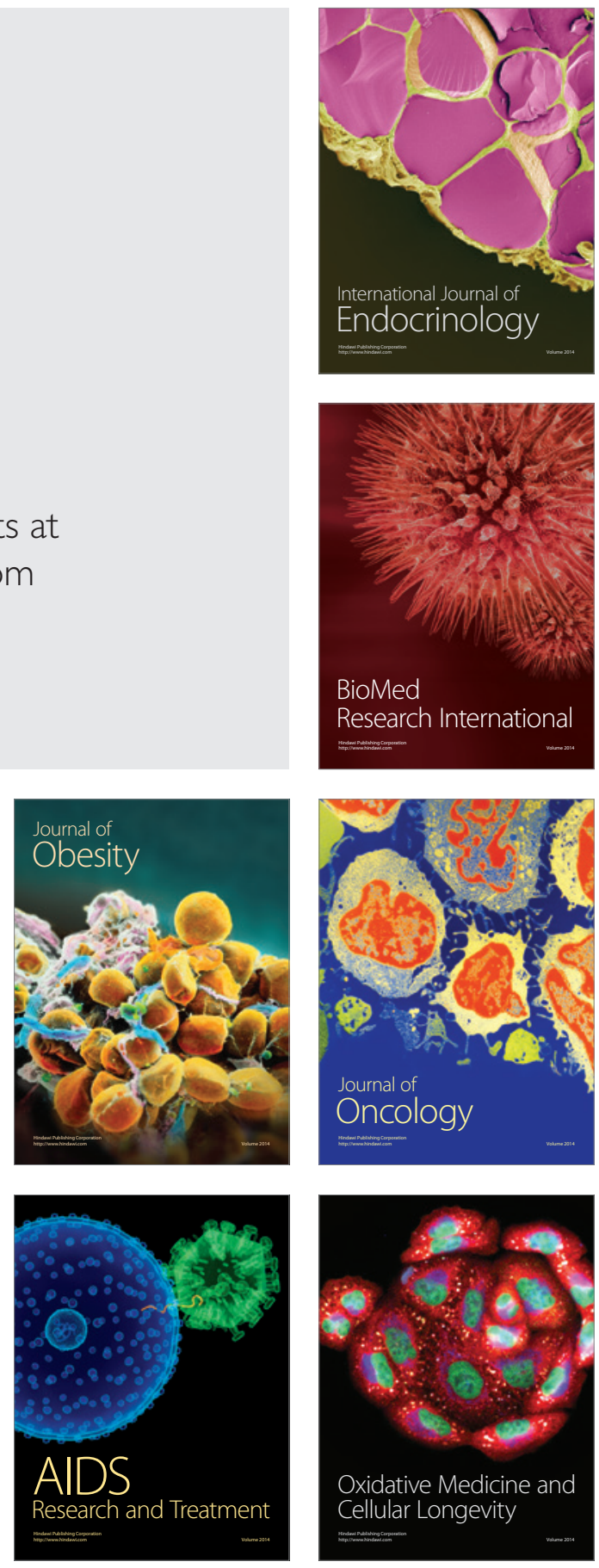